\title{
The Effect of Road Safety Education on Knowledge, Attitude and Perceived Behavioural Control Regarding Road Safety Among Malaysian School Students
}

\author{
Hairul Nizam Ismail, Ahmad Zamri Khairani*, Syed Mohamad Syed Abdullah, Zarina Mustafa, \\ Syamsol Azhar Zulkafli
}

School of Educational Studies, Universiti Sains Malaysia, Malaysia

Received August 24, 2019; Revised November 7, 2019; Accepted November 16, 2019

Copyright $\bigcirc 2019$ by authors, all rights reserved. Authors agree that this article remains permanently open access under the terms of the Creative Commons Attribution License 4.0 International License

\begin{abstract}
The purpose of this study is to examine the effectiveness of the revised road safety education module in enhancing knowledge, attitude and perceived behavioural control regarding road safety among school students. Data were gathered from a total of 835 students aged 15 years old $($ male $=381$, female $=454$ ) from six states across Malaysia. The samples were divided into treatment and control groups. The revised road safety module was supplied to the treatment group, whereas the control group did not use any module. For this purpose, a self-developed survey was employed to gauge responses. Data were analysed using IBM SPSS 22.0 software. The ANCOVA suggested that the treatment group demonstrated significantly higher mean scores in the post-test for both the knowledge and attitude towards road safety compared to the control group. However, no significant difference between the groups was reported for the construct of perceived behavioural control. The outcome of this research shall provide information to agencies such as the Road Safety Department of Malaysia and the Malaysian Institute of Road Safety Research to plan implementation of the revised module to all schools in 2020 .
\end{abstract}

Keywords Attitude, Knowledge, Malaysia, Perceived Behavioural Control, Road Safety Education, School Students

\section{Introduction}

According to [1], a total of 533875 accidents were reported in Malaysia in 2017. As a consequence, 6740 fatalities, 3310 severe and 6539 light injuries were reported. Meanwhile, [2] predicted that the number of road fatalities might well increase to more than 10000 in 2020. Meanwhile, data from the [3] showed that transport accidents (4.6\%) were ranked fourth in the principle causes of death, after ischemic heart diseases (13.9\%), pneumonia (12.7\%), and cerebrovascular diseases (7.1\%). However, for the population of 15 - 40 years old, transport accident was recorded as the principle cause of death at the rate of $22.5 \%$. Although there are still no exact statistics available, accidents involving younger students are also expected to be high. This is due to the fact that younger students are vulnerable to road users because they are inexperienced on roads. In addition, as rightly observed by [4] smaller stature of the young students made them less visible to other road users. Meanwhile, other researchers such as [5], as well as [6], emphasized on the cognitive ability of younger students. According to them, poor cognitive ability of young students has detrimental effect on their ability in identifying hazards when crossing roads. Also, poor cognitive ability may result in difficulty among the young students to pay attention from one task to another which is very essential when using roads.

It should be noted that injury among students is considered more severe compared to adults. An injured child will require constant care that in turn deprives them from many opportunities associated with their age. For example, if a child is hospitalised, he or she will definitely miss school and other school-related activities. Fully aware of the statistics, the government, through the Ministry of Transport, set up the Road Safety Plan 2006 - 2010, with the aim of alleviating and reducing accidents among students. One of the strategies was to introduce road safety education (RSE) at school. The RSE was also treated as a lifelong process and should start at the elementary level [7].

According to [8], the main objective of RSE is to minimise the number of accidents and fatalities. [9] quoted 
that the RSE programmes can be divided into two broad categories, namely, the cognitive and the fear-appeal programmes. Interventions in the cognitive programmes were aimed at enhancing students' understanding and insights regarding their risk-taking behaviour. This is because it was assumed that transferring information as well as personal experiences is adequate for behavioural changes among the students. Thus, activities such as talks and demonstrations on safety behaviour of road users are important agendas in the cognitive programmes. Meanwhile, the main objective of the fear-appeal programmes is to inform the students about road safety risks through evoking fear. This is often done by providing caution to them especially through provoking fear and adverse consequences of risk behaviour. This can also be done through testimonies by victims of road accidents or by showing impact of accidents.

Based on the abovementioned description, the implementation of RSE in Malaysia falls into the cognitive category. In Malaysia, RSE was implemented through incorporating RSE module into the teaching and learning. The RSE module was initiated by the Ministry of Education and implemented in all primary schools starting from the year 2008; while for secondary school, the program was started in 2012. The aim of the RSE module was to inculcate the positive attitudes towards road safety practices [10]. The following approaches were underlined for the implementation of the RSE module.

1. The RSE was implemented by embedding the knowledge during the teaching and learning of Bahasa Melayu (Malay Language) subject.

2. Even though the RSE knowledge was embedded, the focus of teaching and learning process is still on language skills, namely, listening, speaking, reading, and writing.

3. The RSE was implemented once a week in the primary schools and twice a month (in the first and third week) for the secondary schools.

4. The RSE module was provided to teachers as teaching aids, while students were provided with the RSE activity books to be completed as workbook.

5. Teachers had the freedom to choose the day, time and language skills (listening, speaking, reading, or writing) they wanted to incorporate into the RSE during the teaching and learning process.

Contents of the RSE module were based on the themes from the road safety curriculum provided by the Road Safety Department (JKJR) and the Malay Language subject curriculum by the Curriculum Development Division, Ministry of Education. Examples of the RSE contents for the primary and the secondary school are given in Table 1 [10].

Table 1. Examples of the Contents of the RSE Module

\begin{tabular}{|c|c|c|l|}
\hline School & Theme & Focus & \multicolumn{1}{c|}{ Sub-focus } \\
\hline Primary & $\begin{array}{c}\text { Road } \\
\text { environment }\end{array}$ & $\begin{array}{c}\text { Types of } \\
\text { roads }\end{array}$ & $\begin{array}{l}\text { Understanding that roads are complex and dangerous places. } \\
\text { Defining traffic in their own language } \\
\text { Classifying roads in terms of quietness, busy, width, and narrow. } \\
\text { Explaining different types of roads in Malaysia and that vehicles are moving at different } \\
\text { speeds in each type of road. } \\
\text { Identifying elements of transport environment that helps us be safer, or harm us, when } \\
\text { walking or cycling }\end{array}$ \\
\hline Secondary & Road use & Risks and \\
its impacts & $\begin{array}{l}\text { Identifying and listing the factors related to road accidents in Malaysia. } \\
\text { Identifying and listing the impacts of road accidents in Malaysia. Stating the meaning of } \\
\text { risks, and taking risks and the implications of risks in general. Stating the relevance of the } \\
\text { risks, and taking risks with the road use behaviour } \\
\text { Stating the relevance of the risks, the risks and the implications of the risks to the road } \\
\text { environment and travel situation } \\
\text { Identifying risk factors that affect the safety of teens as road users Listing behaviours that } \\
\text { affect the safety of all road users } \\
\text { Stating the consequences of unsafe road use }\end{array}$ \\
\hline
\end{tabular}


In 2014, the technical committee decided that the RSE module required revision since it had been run for the full circle. A study was conducted and results showed that the RSE module required improvement in terms of contents of the activity books and skills on road safety [11]. Therefore, the work for the revised RSE module was conducted by Malaysian Institute of Road Safety Research (MIROS) in 2016 through a series of workshops with stakeholders such as school teachers, officers from the Ministry of Education, the Royal Malaysian Police, as well as panels and subject matter experts from local universities. The final revised module was developed in 2016 for the primary schools, and for the secondary schools in 2018. The revised module was established with the following objectives [12]:

1. To develop knowledge and understanding regarding the concepts of influencing safety among road users.

2. To develop safety-orientation positive attitudes and values, as well as understanding ways of influencing their attitudes

3. To develop road safety skills which focus on self-management, good decision making, communication skills and interpersonal skills.

Critics have argued that the RSE programmes are often implemented without evidence of their actual effectiveness [13]. As such, a large scale pilot study was conducted in 2017 (primary schools) and 2018 (secondary schools). The objective of the study was to evaluate the effectiveness of the RSE in the following perspectives [11]:

1. Knowledge, attitude and perceived behaviour

2. Observational study on safe practices

3. Children's influence on parents' road use behaviour

Therefore, the purpose of this article was to report the findings of the pilot study in relation to the first objective for the secondary schools. Findings from the study should shed some lights especially with regards to the adequacy of the revised RSE module in enhancing students' knowledge, attitude and perceived behaviour regarding road safety. In addition, this study is also important to suggest improvement to the revised module in terms of its contents and implementation.

\section{Literature Review}

As rightly observed by [14], schools are the appropriate places to reach out to students and inform them about road safety. As such, it is not unusual that many EU countries have adapted the policy of implementing the RSE in school. For example, the MobileKids initiative was conducted in countries such as the United Kingdom, Germany, France, Brazil, and Mexico to help students to be safe and prevent accidents. Companies such as Toyota also actively encourage road safety among children in various countries such as Thailand (White Road Campaign), Vietnam (Toyota Safety Driving Program), Argentina (Toyota Vos) and Australia (Toyota Community Foundation for a safe traffic environment). Recently, Total and Michelin, two global players in mobility from France, launched the Worldwide Road Safety Education Programme to educate 8 - 10 years old students in France, Cameroon, and India.

One important aspect that has become central in discussion is the best method used for teaching the RSE. According to a review in a study by [15], providing classroom instruction is a popular mode for teaching the RSE. One of the possible explanations is that this classroom-based programme, which includes the use of books, videos, and lectures, is easy to be administered and incurs low cost. Moreover, the presence of teacher is also helpful in ensuring such programmes [16]. Some of the classroom-based RSE programmes include "Cyrus the Centipede's Pedestrian Safety Program" for $5-8$ years old in the United States, Traffic Informer Programme (Netherlands), Think First Hard Heads Programme for kids between 4 to 6 years old (Canada).

However, there are also arguments on the effectiveness of the classroom-based RSE programmes. Among other, [17] argued that classroom-based approaches are inferior. One of the reasons is that it focuses too much on the knowledge but lacks practical road safety skills [18]. The support for more behavioural aspects in the RSE is further justified through a review by [19]. They found that the inclusion of behavioural intervention not only helps to retain the children's knowledge, but also improves their safety. From the perspective of developmental psychology, it is argued that learning is context-specific. That is, when students learn in classrooms, it is difficult for them to transfer the experience to other contexts such as on the roadside. As such, there is a need for the students to have real world interaction [20] so that they are aware of the traffic in real situation. Also, real world activities enable students to learn basic road safety practices. [21] suggested that the RSE should include real-life situations as close as possible in order to strengthen their positive behaviour towards safety. However, bringing students to roadside should be done with full supervision from adults.

Since the RSE targets students, it is important for the programmes to take into consideration their development as well [22]. It should be noted that for every activity on the road, there are specific skills that students need to acquire to ensure their safety. These skills are not most probably similar to adolescents or adults. For example, while it only requires good judgment for adolescents and adults, [23] listed five fundamental skills that children need to acquire in order to cross a road safely. Firstly, the students need to have skills in detecting the present traffic. This includes the ability to search for vehicle movement as well as understanding traffic movements. Secondly, the students also need to have the skills to identify the sources of danger or distractions. Thirdly, in order to cross the road safely, the students also must have the skills to estimate speed as well as accurate time-to-contact judgments. Fourthly, the 
students also require the skills to coordinate information gathered from various senses and sources, and finally, they need to understand their own capabilities - such as how fast they can move. Also, it is highly likely that the mentioned skills differ from one student to another due to variables such as gender, age, and experiences as road users. As such, good RSE programmes should take into consideration students' development in their implementation.

\section{Methodology}

\subsection{Sample}

The sample consisted of 835 Form 3 students (average age $=15$ years old) who were derived from six locations across six states in Malaysia. Noting that in Malaysia, the grade level was based on age of the students, in which the average age for Form 1 was 13 years old, while for Form 2 students, their average age was 14 years old. Table 2 shows the demographic information of the sample. The six locations were selected based on the reports of the highest number of accidents involving users aged 13 to 16 years old between 2010 and 2015 according to the statistics provided by the Royal Malaysian Police.

Table 2. Demographic information of the sample.

\begin{tabular}{|c|c|c|}
\hline Demographic & $\mathrm{N}$ & $\%$ \\
\hline District (State) & & \\
\hline Lower Perak (Perak) & 146 & 17.5 \\
\hline Central Malacca (Malacca) & 126 & 15.1 \\
\hline Kota Kinabalu (Sabah) & 137 & 16.4 \\
\hline Kajang (Kuala Lumpur) & 119 & 14.3 \\
\hline Labuan (Labuan) & 152 & 18.2 \\
\hline Kuala Terengganu (Terengganu) & 155 & 18.6 \\
\hline Gender & & \\
\hline Male & 381 & 45.6 \\
\hline Female & 454 & 54.4 \\
\hline Group & & \\
\hline Treatment & 438 & 52.5 \\
\hline Control & 397 & 47.5 \\
\hline
\end{tabular}

The sample was divided into two groups, namely, the treatment and the control groups. In each district, two schools were randomly selected for the treatment group, while two others were selected for the control group. As such, there were a total of 12 treatment schools and 12 control schools in this study. The treatment group used the revised RSE module whereas no module was employed for the control group. The treatment group used the revised RSE module for a duration of eight months.

\subsection{Instrument}

In this study, the knowledge construct was measured using a 20-item self-developed multiple-choice test. In particular, it measured various aspects of students' knowledge on road safety. The test was developed in the Malay Language. It was dichotomously scored, where the correct answer was scored 1, and an incorrect answer was scored 0 . The items were developed directly from the contents of the RSE revised module. For example, Activity 1 in the module was developed for the following learning outcome: To measure learning outcome of describing the importance of using apparel and safety equipment to ride a motorcycle. For this purpose, the following items were developed to measure the intended learning outcome, as follows:

\begin{tabular}{|c|c|l|}
\hline \multirow{1}{*}{1} & $\begin{array}{l}\text { Mengapakah memandu sambil berswafoto (selfie) berisiko } \\
\text { kemalangan? } \\
\text { (Why does taking selfie while driving can cause accident?) }\end{array}$ \\
\cline { 2 - 3 } & $\mathrm{A}$ & Menghalang lalu lintas. Preventing traffic. \\
\cline { 2 - 3 } & $\mathrm{B}$ & $\begin{array}{l}\text { Pemandu mungkin hilang kawalan. } \\
\text { Drivers may lose control. }\end{array}$ \\
\hline \multirow{2}{*}{$\mathrm{C}$} & $\begin{array}{l}\text { Gambar yang diambil berkualiti rendah. } \\
\text { Images taken are of low quality. }\end{array}$ \\
\hline $\mathrm{D}$ & $\begin{array}{l}\text { Sukar memfokus kamera/telefon. } \\
\text { Difficult to focus the camera/phone. }\end{array}$ \\
\hline
\end{tabular}

The samples' attitude towards road safety was measured using the self-developed questionnaire consisting of 13 items. The attitude towards road safety was conceptualised in three components, namely, cognitive, affective, and behavioural components. All the items were developed from the contents of the revised module, as well as past studies related to the perceived behavioural control such as [24]. Examples of the items are given in Table 3 .

Table 3. Examples of the Items

\begin{tabular}{|c|l|}
\hline Component & \multicolumn{1}{|c|}{ Sample of the Items } \\
\hline Cognitive & $\begin{array}{l}\text { Accidents are caused by human errors or } \\
\text { carelessness }\end{array}$ \\
\hline Affective & $\begin{array}{l}\text { Road safety education can improve the quality of } \\
\text { road usage }\end{array}$ \\
\hline Behavioural & I like to ride the bicycle with a pillion* \\
\hline
\end{tabular}

* negatively worded item

Meanwhile, items related to the perceived behavioural control were developed based on the researchers' operationalization of the topics and learning outcomes of the revised RSE module. This is because research on the perceived behavioural control regarding road safety is almost non-existent. Examples of the 10-items instrument are given in Table 4.

Table 4. Examples of the Items

\begin{tabular}{|c|c|c|}
\hline Topic & Learning Outcome & Example of the Items \\
\hline $\begin{array}{c}\text { Behaviour } \\
\text { and Risk }\end{array}$ & $\begin{array}{c}\text { Stating ways to } \\
\text { address risks related } \\
\text { to road users } \\
\text { behaviour }\end{array}$ & $\begin{array}{c}\text { I myself determine the } \\
\text { way to handle the risks on } \\
\text { the road and no other } \\
\text { people. }\end{array}$ \\
\hline
\end{tabular}




\subsection{Data Collection}

Data were collected in two occasions; in February and in October after the permission had been granted from the Ministry of Education and the state education departments. On both occasions, the students were assembled in special rooms such as library, lecture hall or meeting room as the researchers needed to brief them on how to respond to the instrument. In total, it took about 30 minutes to answer all the questions/items.

\subsection{Data Analysis}

Data entry was done using the IBM SPSS 22.0. Descriptive statistics such as mean and standard deviation were reported to provide an overview of the measurement. In addition, comparisons between the treatment and control groups were conducted using the analysis of covariance (ANCOVA). The pre-test scores were used as covariates whereas the post-test scores represented the dependent variables. Types of group (treatment, control) were treated as the independent variables.

\section{Results and Discussion}

The following table shows the mean and standard deviation (SD) for the treatment and control groups. It shows that for the construct of knowledge, the treatment groups recorded higher mean score compared to the control group. A similar trend is also reported for the post-test scores. Meanwhile, despite having lower pre-test scores, the treatment group managed to record higher mean scores in the post-tests for both the attitude and perceived behavioural control.

Table 5. Descriptive Statistics

\begin{tabular}{|c|c|c|c|c|c|}
\hline \multirow{2}{*}{ Construct } & \multirow{2}{*}{ Group } & \multicolumn{2}{|c|}{ Mean } & \multicolumn{2}{c|}{ SD } \\
\cline { 3 - 6 } & & Pre-test & Post-test & Pre-test & Post-test \\
\hline \multirow{2}{*}{ Knowledge } & Treatment & 12.15 & 13.05 & 3.04 & 2.95 \\
\cline { 2 - 6 } & Control & 11.37 & 12.27 & 3.75 & 2.96 \\
\hline \multirow{2}{*}{ Attitude } & Treatment & 36.70 & 37.22 & 3.48 & 3.46 \\
\cline { 2 - 6 } & Control & 36.79 & 36.62 & 3.26 & 3.39 \\
\hline $\begin{array}{c}\text { Perceived } \\
\text { Behavioural } \\
\text { Control }\end{array}$ & Treatment & 30.52 & 28.94 & 3.22 & 2.63 \\
\cline { 2 - 6 } & Control & 30.61 & 28.81 & 3.21 & 2.53 \\
\hline
\end{tabular}

Results from ANCOVA showed that there is a significant main effect of the types of group on knowledge about road safety $[F(1,831)=9.165, p=.003$, partial eta squared $=.011]$ after controlling on the prior knowledge score (the pre-test score) of the students. In more specific terms, students demonstrated significantly higher scores when exposed to the revised RSE module. The finding was consistent with the results from evaluation of the previous RSE module conducted by [25], as well as [26]. As for the attitude towards road safety, the present study found significant main effect of the types of group safety [F $(1,831)=9.885, \mathrm{p}=.002$, partial eta squared $=.012]$ after controlling on the pre-test scores. Both the results were expected since the RSE module was specifically designed to improve students' knowledge and ultimate attitude towards road safety. This is because the revised module was carefully developed to cultivate safety-oriented knowledge, attitude and values [12]. For example, the module consisted of various pages of advice, best practices, as well as the dos and the don'ts regarding road safety. In addition, the module also showed misbehaviours and implications when road safety was not heeded. This information certainly helps students to gain better knowledge, which in turn, encourages a more positive attitude towards road safety.

Meanwhile, with regards to the perceived behavioural control, the present study showed no significant main effect of the types of groups $[F(1,832)=.610, p=.435$, partial eta squared $=.001]$ after controlling on the pre-test score. That is, the intervention RSE programme was not able to enhance the students' perceptions on their ability to perform appropriate behaviour such as advising speeding school bus driver to slow down. In other words, even though introducing the RSE module resulted in the change of both knowledge and attitude, there is little evidence to show that the programme was able to change behaviour of the students. The result is not consistent with the finding of, [27] that reported positive effect of RSE on students' perceived behavioural control. This is rather unfortunate since it is the user's behaviours that are considered an important factor causing accidents. For example, the research by [28] revealed that behaviours identified as speeding, traffic errors, and safety violation were important predictors that cause road crash among young motorcyclists in Malaysia. They also identified that (1) crossing a junction while the traffic light is red, and (2) exceeding the speed limit on a motorway as the two most frequently reported behaviours.

As such, it is perhaps important for the relevant agencies to relook at the approach of the RSE programme. For example, it should be noted that even though the current classroom-based programme might have several advantages in term of implementation, the approach did not provide opportunity to change the students' behaviour regarding road safety. In the revised module, for instance, it was suggested that teacher should teach the topic of visibility for road users using video clips. After showing the video clips, students were encouraged to express their opinions on the possible situations road users might get themselves in in the video [12]. However, it should be noted that in real situations, there are a lot more contextual parameters such as road visibility, street lightings, the number of road users, and timing that could influence the decisions to use the road. Therefore, we suggest that the RSE should also involve real world interactions so that students are made fully aware of all the parameters involved. More importantly, involving the students with 
real situations may help them learn basic road safety skills directly or indirectly.

Nonetheless, one important area that requires further investigation is the fact that the pre-test scores were found to be significant predictors to the post-test scores for the constructs of knowledge, attitude, and perceived behavioural control. This warrants further study because the sample of students in this study had already been introduced to the RSE module since Form 1. Hence, one might speculate that their experiences within the three years might have influenced the results of this study. In addition, road safety campaigns were also often broadcast on TV stations, radios, social media and even theatres. Students might also have benefitted from these campaigns particularly in increasing their knowledge, attitude, and/or perceived behavioural control about road safety. Therefore, results from understanding students' prior experience are also important to evaluate the adequacy of the contents of the module. In other words, the contents should not be seen as repeating previous module as otherwise students might get bored. Instead, the revised module should be developed to encourage the students to use their prior knowledge in making decisions about the best practices as road users. This is because at their age ( 15 years old), it marks the end of the RSE for the students, and for some of them, they will become active road users. This is because in Malaysia, the students are eligible to apply licence for riding a motorcycle at the age of 16 years old.

\section{Conclusions and Recommendations}

In this study, we have presented empirical evidence on the effectiveness of the revised RSE module in enhancing students' knowledge and attitude. However, in order to ensure the success of the programme, it is important to conduct a study on teachers' perception of the RSE in school. This is important since teachers are known to be an important variable that can influence the success of any program in school. The study may include information on how well the teachers perceive its usefulness, and more importantly, what the best practice to be used in implementation of the RSE module is. In addition, the study might also reveal weaknesses of the existing module so that these can be rectified before implementing the revised module. For example, one might speculate that embedding the revised RSE module in the subject Bahasa Melayu might experience time constrain since the Form 3 students are sitting for the high-stake national level Pentaksiran Tahap 3 (Level 3 Assessment).

\section{Acknowledgements}

We would like to thank the Road Safety Department of Malaysia for funding this research. We also would like to thank the Malaysian Institute of Road Safety Research and the Universiti Sains Malaysia for making this research possible.

\section{REFERENCES}

[1] Ministry of Transport (2018), Buku statistik kemalangan jalan raya (Road safety statistic book). Retrieved from http://www.jkjr.gov.my/en/safety-info/road-safety-statistic/ func-startdown/139/lang,en-gb/

[2] R. Sarani, S. A. S. M. Rahim, J. M. Marjan, S. V. Wong, (2012). Predicting Malaysian road fatalities for year 2020. Kajang: MIROS

[3] Department of Statistics (2017). Perangkaan sebab kematian (Cause of death statistics). Retrieved from https://www.do sm.gov.my/v1/index.php? $\mathrm{r}=$ column/pdfPrev\&id $=\mathrm{cmVSV}$ GovZklwZEtlREFHTW1XY1FOUT09

[4] T. Toroyan, M. Peden. Youth and road safety. Geneva: World Health Organization. 2007.

[5] G. Dunbar, R. Hill, V. Lewis. Children's attentional skills and road behaviour. Journal of Experiment Psychology: Applied, Vol. 7, 227-234

[6] M. S. Zeedyk, L. Wallace, L. Spry. Stop, looks, listen, and think? What young children really do when crossing the road. Accident Analysis and Prevention, Vol. 24, 43-50.

[7] N. Othman, S. N. Jamaludin, R. Shahril, M. Musa, A Shabadin, A. H. A. Ghani, S. F. Low, S. V. Wong Semakan semula modul pendidikan keselamatan jalan raya (PKJR) sekolah rendah dan sekolah menengah: Kajian pandangan guru dan penilaian pakar bidang (Review of primary and secondary road safety education (PKJR) modules: Teachers' views and evaluation of field specialists). Kajang: MIROS. 2016.

[8] OECD (1986). Effectiveness of road safety education programmes. Paris: OECD.

[9] D. Twisk, W. Vlakveld, J. J. F. Commandeur, J. T. Shope, G Kok. Five road safety education programmes for young adolescents: a multi-programme evaluation. Accident Analysis \& Prevention, Vol. 66, 55-61.

[10] Ministry of Education. Panduan perlaksanaan pendidikan keselamatan jalan raya (Guideline for road safety education). Putrajaya: Ministry of Education. 2016.

[11] H. Hussain, S. F. Low, T. H. Law, K. S. Tan, C. P. Ng, M. N. Nur Afifah, A. G. Amelia Hazreena, \& M. S. Nurfatin Nadia. Evaluation of the revised road safety education modules for primary schools. Kajang: MIROS. 2018.

[12] Road Safety Department of Malaysia. Pendidikan keselamatan jalan raya dalam mata pelajaran Bahasa Melayu: Buku panduan guru (Edisi rintis) [Road safety education in the Malay Language: Teachers' guide book (pilot edition)]. Putrajaya: Road Safety Department of Malaysia. 2018.

[13] N. Dragutinovic, D.a.M Twisk. The effectiveness of road safety education, a literature review. SWOV Institute for Road Safety Research, Leidschendam. 2016. 
[14] Weber, K. "ROSE 25: Inventory and compiling of a European good practice guide on road safety education targeted at young people. Final Report for European DG TREN." 2005.

[15] S. N. Jamaluddin, N. Othman, S. F. Low, S. V. Wong. Effective instructional method of road safety education: A review. Kajang: MIROS. 2016.

[16] D. S. Berry, C. V. Romo. Should 'Cyrus the Centipede' take a hike? Effects of exposure to a pedestrian safety program on children's safety knowledge and self-reported behaviors. Journal of Safety Research, Vol. 37, No. 4, 333-341.

[17] J. Thomson, A. Tolmie, H. C. Foot, B. McLaren. Child development and the aims of road safety education. Department of Transport: Road Safety Research Report 8, Road Safety Division. London: HMSO. 1996.

[18] M. S. Zeedyk, L. Wallace, B. Carcary, B., K. Jones, K. Larter. Children and road safety: Increasing knowledge does not improve behaviour. British Journal of Educational Psychology, Vol. 71, No. 4, 573-594.

[19] D. C. Schwebel, L. A. McClure. Training children in pedestrian safety: Distinguishing gains in knowledge from gains in safe behaviour. The Journal of Primary Prevention, Vol. 35, No. 3, 151-162.

[20] M. S. Zeedyk, L. Kelly, L. Behavioral observations of adultchild pairs at pedestrian crossings. Accident Analysis Prevention, Vol. 35, 771-776.

[21] A. Trifunovic', D. Pešic', S. C C ic evic', B. Antic'. The importance of spatial orientation and knowledge of traffic signs for children's traffic safety. Accident Analysis Prevention, Vol. 102, 81-92.

[22] F. Alonso, C. Esteban, S. Useche, N. Colomer, 2018 International Journal of Environmental Research and Public Health, Vol.15, No.12.

[23] H. Foot, A. Tolmie, J. Thomson, B. McLaren, K. Whelan. Recognising the hazards. The psychologist, Vol.12, No.8, 400-402.

[24] Z. Bidin, M. F. A. Md Hashim, Z. Sharif, Mohd-F. Shamsudin. Using the Theory of Planned Behaviour (TPB) in Predicting the Intent to Use the Internet for Academic Purposes. Malaysian Journal of Learning \& Instruction, Vol 8, 138-190.

[25] Hashim, A. H., Assim, M. I. S. A., Redzuan, M., Abdullah, A., \& Senin, E. A. (2008). Road safety education: the effectiveness of road safety educational module of knowledge among year 1, 2, \& 4 students. Road Safety Research, Universiti Putra Malaysia.

[26] Mani, K. K. C. et al. (2011). Evaluation of Road Saftey Education Program in Primary School in Malaysia. Universiti Putra Malaysia, Serdang Selangor.

[27] Ismail, M., Assim, M. I. S. A., Hashim, A. H., \& Sabri, M. F. (2016), Kesan pendidikan keselamatan jalan raya terhadap tingkah laku berencana pengguna jalan raya dalam kalangan kanak-kanak (The effect of road safety education towards perceived behavioural control road users among children). Jurnal Pengguna Malaysia, Vol. 26, 18-35.

[28] Azman, N. S., Mohamad, N. A., Rashid, A. A. A., Yei, S. A. L. S., Low, S. F., Wong, S. V. (2017). Safety violations, traffic errors and speeding as contributing factors in road crashes among young motorcyclists in Klang Valley. Kajang: MIROS 